Open Access

\title{
Does Chinese OFDI really promote export?
}

\author{
Chih-Fan Lin
}

\author{
Correspondence: \\ lopez193@foxmail.com \\ The Wang Yanan Institute for \\ Studies in Economics, Xiamen \\ University, No. 422 of Siming South \\ Road, Siming District, Xiamen City, \\ Fujian Province, People's Republic \\ of China
}

\begin{abstract}
Background: Most papers have come to positive conclusions regarding whether Chinese outward foreign direct investment really promote export.

Methods: This paper contributes by correcting model misspecification, wrong variable selection and estimation methods which are prevalent in existing studies and reexamine the relationship between outward foreign direct investment and export trade of China using panel data from 2003 to 2014.

Results: The regressions indicate that, on average, the point estimate of the elasticity between Chinese outward foreign direct investment and export trade is at most 0 . 073, and it is not statistically significant. Sub-sample regressions show that Chinese investment in developed economies slightly substitutes export while investment in developing economies complements export. But these effects disappear when country-specific effects are controlled. Year-by-year regressions show that the complementary effect of OFDI on export is on a steady rise.
\end{abstract}

Conclusions: Using correctly specified model with more appropriate variable selection and estimation methods and take into account the quantitative difference between OFDI and export, any "substitutionary" or "complementary" effect is indeed negligible.

Keywords: Outward foreign direct investment, Export, Complementation effect, Substitution effect

\section{Background} Introduction

With the continuous growth of Chinese economy, Chinese outward foreign direct investment develops rapidly. From the year of 2003 when the "statistical bulletin of Chinese foreign direct" was first published to the year of 2014, Chinese foreign direct investment flow grew from $\$ 28.5$ billion to $\$ 1231.2$ billion and the accumulated stock grew from $\$ 299$ billion to $\$ 8826.4$ billion, with the average annual growth rate being 40.8 and $36.0 \%$, respectively. In 2014, Chinese foreign direct investment accounted for 9.1 and $3.4 \%$ of global flow and stock, respectively, ranks the third and eighth in the world; 18.5 thousand Chinese investors have set up 29.7 thousand enterprises that distribute in 186 foreign countries (territories), which indicates that China has gradually developed from a capital attraction country to an investment country. At the same time, China has long become a major exporting economy since the 1990s. China's total exports in 2014 amounted to $\$ 2.34$ trillion, ranking first in the world. In the new background that China actively promotes the "One Belt and One Road" strategy in neighboring countries, it is a greater development opportunity for Chinese foreign direct investment, which makes the effect of foreign

(c) The Author(s). 2016 Open Access This article is distributed under the terms of the Creative Commons Attribution 4.0 International License (http://creativecommons.org/licenses/by/4.0/), which permits unrestricted use, distribution, and reproduction in any medium provided you give appropriate credit to the original author(s) and the source, provide a link to the Creative Commons license, and indicate if changes were made. 
direct investment on export trade an important issue. Different conclusions indicate different policy implications: if the OFDI of China had a promoting effect on exports, it would be necessary to take potential trade frictions and dispute risks into consideration and to properly manage the expanding trade surplus and exchange pressures on RMB. If the OFDI of China had a substitution effect on export, it would be necessary to assess the negative effect of capital export and shrinking export on domestic economic growth and employment in order to avoid the repeating mistake of industrial hollowing-out caused by OFDI as some developed countries have experienced in history (Liu and Nie 2014).

Classical literatures have fully discussed the effect of OFDI on exports: Based on the Heckscher-Ohlin international trade model, Mundell (1957) demonstrated that if the two economies have similar production functions and consumer demands, international direct capital investment would equalize the factor endowment structure and the relative prices. Commodities originally produced and exported would now be produced in another country through the flow of production factors. In this sense, the flow of production factor capital is equal to that of goods, which indicates that export would be replaced. However, Schmitz and Helmberger (1970) suggested that the analysis framework was only suitable to intraindustry trade of manufactured goods. When developed countries invested in the developing countries with abundant natural resources, the capital country exports machines, equipments, and other capital goods to the host country while the host country exports crude oil, iron ore, and other primary products. This investment-trade pattern would increase international trade. More broadly speaking, when the capital country and host country have vertical division of labor, OFDI would promote the export of intermediate goods of the capital country (Helpman 1984). The theory of product life cycle provides another perspective: Vernon (1966) pointed out that in the early life stage of a product, $R \& D$ and the export of the product were carried out in the domestic countries. In the mature and decline period, rising production costs would make the rational firms transfer the production process to other countries with low factor cost through direct investment, which would lead to less export. Kojima (1975) held a different view and he suggested that the transfer of "marginal industries" that have lost the comparative advantage would promote the export of capital goods and intermediate products to the host country, which indicates that FDI would increase the export. At the same time, the capital country would import manufactured goods from the host country. The foreign direct investment and gradient industrial transfer with Japan acting as the leading goose had a significant positive effect on the international trade and economic growth in East Asia in the 1980s or 1990s of the last century.

There are other literatures exploring the relationship between FDI and export from the perspective of firm decision-making. Hirsch (1976) pointed out that the multinational corporation had two alternative ways for entering the foreign markets: export and FDI. Firms made rational decisions based on domestic and foreign production costs, transportation costs, sales costs, and other factors. He also thought that it was tariff that pushes the export costs of firms, which made the tariff-jumping become one of the causes of FDI. Buckley and Casson (1981) considered the effects of market demand size: For firms, export had a higher marginal cost due to international shipping, customs duties, and other factors, but the fixed cost is low, which is suitable for meeting smaller market demands. Establishing factories in foreign countries, on the other hand, entails higher fixed costs but lower marginal costs, which is suitable for meeting larger market demands. When the foreign market demand grows rapidly, the 
firm would prefer the foreign direct investment that has the advantage of economy of scale. In the framework of cost analysis, foreign direct investment and export trade are mutually substituted. However, cost is not the only factor. Helpman (1984) considered that with respect to the host companies, the multinational corporations tend to have more advanced production technology, management, and R\&D capability. For the maintenance of these unique advantages and avoiding imitation of competitors, multinational corporations may be unwilling to make external market transactions, but prefer intra-firm trade that purchases machinery equipment and intermediate goods from host country, which increases the export of host country. In addition, in the trade theory of heterogeneous firms (Helpman et al. 2004), it is productivity that determines the way that firms enter foreign markets: firms with higher productivity, larger scale, and more abundant resources can pay a higher upfront costs, bear higher risk, and also tend to enter foreign market in the way of direct investment. On the contrary, firms with lower productivity would choose the exporting mode with low fixed cost. Foreign direct investment and exporting are two kinds of alternative endogenous choices.

The above theoretical literatures have reached no consensus. Similarly, among empirical literatures concerning other countries, some supports the complementation effect (Lipsey and Weiss 1981, 1984; Head and Ries 2001; Chen and Tang 2014) while others support the substitution effect (Horst 1972; Belderbos and Sleuwaegen 1998; Oberhofer and Pfaffermayr 2012). In a word, the investment in different countries, industries, development stages, and of different motivations shows different effects on exports.

However, obviously different from foreign literatures, domestic researches are strikingly consistent, nearly all of them showing that Chinese FDI significantly promotes exports. But this paper finds that these conclusions are doubtful due to the disadvantages of variable selection, model setting, and estimation methods. The estimation of the potential impact of FDI in the situation of "One Belt and One Road" depends on the accuracy and robustness of empirical research. Therefore, the marginal contribution of this paper is to correct these errors and to reexamine the effect of OFDI on exports using panel data from 2003 to 2014. The conclusion of this paper rejects the common understanding that Chinese FDI promotes the exports. Moreover, this paper also proves that different conclusions are achieved by correcting model misspecification, wrong variable selection, and estimation methods, not due to the use of a different sample.

\section{Conclusions and problems in the existing literature}

Does Chinese FDI really promote export? The existing literatures in China provide affirmative answers. Based on Kojima's theory of "marginal industry," Cai and Liu (2004) asserted that the goal of Chinese investment in less developed countries was to transfer labor-intensive industries that would soon lose cost advantage such as processing manufacture, simple assembly products. They used time series data of outward foreign direct investment, import and export of China from 1990 to 1999 for empirical analysis and got the conclusion that FDI promoted export. Zhang (2005) used the cointegration regression, error correction model, and Granger causality test to estimate time series data of FDI and export from 1982 to 2002 and got the conclusion that FDI promoted export. Zhang (2007) collected panel data of FDI that China invested in 72 countries from 2000 to 2004 . With the averaging method, he acquired a sectional dataset for regressions and got the conclusion that FDI promote export with the gravity 
model. Xiang (2009) used a panel co-integration and error correction model with the FDI data that China invested in 50 countries from 2000 to 2006, and he got the conclusion that FDI can significantly promote export: the estimated elastic coefficient is about 0.9 , which means $1 \%$ increase of FDI would lead to $0.9 \%$ increase of export. Chen et al. (2010) used a single variable regression specification and use the GLS, fixed effect, and random-effects model for the estimation using flow and stock data that China invested in 26 countries from 2003 to 2007 and he got the conclusion that FDI promote export. In addition, latest literatures such as Zhou and Niu (2012). Zhang (2012), Zhang and Huang (2013), Liu and Xie (2014), and Liu et al. (2014) used larger samples for their research. Although there are many differences in model specification and estimation methods, these literatures basically got the same conclusion that the OFDI of China promotes its exports, despite some documented "country heterogeneity". I refrain from further discussions to save space. ${ }^{1}$

Undoubtedly, these papers provide solid foundations for studying the trade effect of OFDI. However, upon reviewing these existing empirical literatures, there are at least three disadvantages.

\section{The selection of the OFDI variable}

The data of OFDI in the current literature is mainly from the "statistical yearbook of China" and "statistical bulletin of Chinese foreign direct investment". They collect the flow and stock data of FDI that China invested in other countries (regions). The flow data records the investment amount that China invests in or withdraws from the host country. Zhang (2007), Chen et al. (2010), Zhang (2012), and Wang et al. (2014) studied the effect of OFDI on trade using flow data. However, it can be seen that situations that withdrawing or the loss of investment which lead to the negative flow OFDI are not rare. I collect panel data of Chinese OFDI from 2003 to 2014 from the statistical bulletin of Chinese foreign direct investment; among the effective 1636 observations of OFDI, there are as many as 124 observations that are negative, which accounts for $7.6 \%$ in the total sample. If I take natural logarithm of the flow data, it is inevitable to delete these negative observations or to replace them with zeroes. The sample selection problem brought by this nonrandom censoring is likely to cause biased results.

Another problem is that the OFDI flow data and trade data may show a strong positive correlation due to some shocks caused by exogenous factors that may be difficult to quantify. For example, when political leaders of China and host countries signed strategic cooperation agreements, bilateral economic and trade cooperation would be promoted in the following years, which leads to both rapid growth of investment flow and trade. On the contrary, occasional deterioration of political relations may lead to simultaneous shrinks of investment flows and trade. In short, OFDI and export have the high positive correlation due to the exogenous political impact, which makes the OFDI show a certain promoting role in the regression with the export as the explanatory variable. However, the endogeneity of simultaneity is essentially due to the unobservable or unquantifiable factors. The relationship is not the focus of attention, so flow data of OFDI is not suitable for research.

In fact, when we study the long-term effect of production and operation brought by OFDI, lagged data of OFDI stock data would be the most reasonable choice. For example, Zhou and Niu (2012), Chih-Fan and Dong (2013), Zhang and Huang (2013), Liu and Xie (2014), and Wang and Xiang (2014) used the current stock data. But since the current 
stock data is calculated based on current flow data, lagged stock data and investment profit. Since it includes information concerning the current flow data of OFDI, the problem of endogenous bias could not be avoided. In reality, no matter OFDI takes the form of merger and acquisition, the legal procedure, site construction, procurement and installation of production equipment, and recruitment and training of production personnel all need to consume a certain amount of time. Instead, lagged data of OFDI stock fully considered the required time lag that investment flow transformed into actual production capacity. Therefore, this paper selected the lagged terms of OFDI stock as the core explanatory variable in empirical analysis. ${ }^{2}$ The paper also provides regression results using current flow data and stock data for comparison. They are based on the same set of sample so the differences between the conclusions are solely attributable to different selections of core explanatory variables. Regression results reveal that with the current flow and stock data as the explanatory variables, the estimated value and significance of promoting effect are overestimated while that of substitution effect are underestimated. The lag of stock data has no promoting effect on export. ${ }^{3}$

\section{The specification of the empirical model}

Limited by data availability, earlier studies used the aggregate time series data with the methods of co-integration regression, error correction model (Cai and Liu 2004; Zhang 2005). Later studies such as Xiang (2009) and Chen et al. (2010) used cross-country panel data; but the idea of co-integration analysis is still followed. The problem with this kind of model specification is that only OFDI is chosen for explaining import and export. The regression setting of "single variable" fails to take other factors into consideration. Since China is a large country with rapid economic growth and actively participate in the globalization of economic activities, its OFDI and export are both on a rising trend. From a quantitative perspective, lacking control variables in regressions will undoubtedly reach the conclusion that these two variables are significantly and positively correlated, which is most probably caused by severe omitted variable bias. What is more, China only began large scale of OFDI after 2005; before then, China's annual OFDI flow was less than ten billion and the stock was only tens of billions, which is difficult to form an impact on export with trillion-dollar-level in an economic sense. Therefore, this paper conducts empirical analysis within the framework of the gravity model, which has been the most popular workhorse in the field of international trade. It includes the major factors of international trade to improve the explanatory power of the model as well as to weaken the impact of missing variables. The results show that the maximum elasticity of OFDI on export in the full sample regression is 0.073 while in the subsample is 0.12 at most. Taking the huge magnitude gap between China OFDI stock and export trade into consideration, the range of the elasticity coefficient is more reasonable compared to those between 0.3 and 0.9 found in previous papers such as Xiang (2009), Zhang (2012), and Liu and Xie (2014).

\section{The choice of model estimation method}

The combination of cross-country panel data and the gravity model has been popular in latest research (Zhou and Niu 2012; Hu and Qiao 2013; Chih-Fan and Dong 2013; 
Zhang and Huang 2013; Wang et al. 2014; Wang and Xiang 2014). The most commonly used estimation method for panel data is the fixed-effects model. If this method was used, time-invariant explanatory variables such as geographical distance, whether the two countries are borders or have the common language, would be classified as individual fixed effects and are consequently unidentifiable, which is a difficult problem in the gravity model.

Existing literatures provide three possible solutions: the first is the pooled OLS or random-effects model. These methods are used to regress for obtaining the estimated coefficients of all variables, but pooled OLS gives up the control of individual heterogeneity, and whether the random-effects model is suitable is uncertain. ${ }^{4}$ Both of them cannot guarantee the consistency of estimations. The second is the varying-coefficient model. This method is used by recent literatures and got the conclusion that some "country heterogeneity" exist in the effect of Chinese OFDI on export trade (Zhang 2012; Liu and Xie 2014). This method is generally applicable to the long panel data (namely that the annual number $T$ is greater than the number of individuals $N$ ). The Chinese OFDI data is a typical short panel, which indicates that the method is not suitable. The third is the dynamic panel data model estimated using system GMM method (Liu et al. 2014). However, what the dynamic model estimates is the shortterm equilibrium relationship but not the long-term impact of OFDI on exports. Moreover, the explanatory variable of Chinese GDP is missed in the gravity model of Liu et al. (2014). Since the OFDI stock of China is positively correlated with GDP, the conclusion that OFDI has a positive effect on export trade is likely a "false impression" caused by omitted variable bias. ${ }^{5}$

The empirical analysis in this paper uses multiple specifications to obtain robust conclusions: I use a pooled OLS model and control for bilateral GDP, geographical distance, lagged OFDI stock as well as heterogeneities that may influence trade in the gravity model. I also use a fixed-effects model to obtain a within-group consistent estimator, but I would not be able to obtain the estimated coefficients for time-invariant variables such as geographical distance. Second, in order to alleviate the endogeneity bias in the gravity model caused by the log-linearized of data that violates the conditions for consistent estimation, I use the Poisson pseudo maximum likelihood estimator suggested by Silva and Tenreyro (2006). The results show that the conclusion in this paper is very robust.

\section{Methods}

In the field of international trade, the gravity model originally proposed by Tinbergen (1962) and developed by Anderson (1979), Bergstrand (1985) has become the standard paradigm of empirical research. Although the gravity model was first proposed as an empirical equation, it has solid theoretical foundations. Some form of the gravity model can be derived from the neo-classical international trade theory based on factor endowment structure and comparative advantage or from the new trade theory based on monopolistic competition. According to the review article of Anderson and van Wincoop (2004), after introducing factors such as per capita income, trade barriers, exchange rates, borders, common language dummies, free trade agreements, and colonial relationship into the 
gravity model, it can explain more than $80 \%$ of international trade flows. It has become one of the most successful empirical models in economics research.

In this paper, the trade gravity model is used as an empirical framework to estimate the export effect of OFDI:

$$
\begin{aligned}
\ln \mathrm{EXP}_{i, t}= & \beta_{1} \ln \mathrm{GDP}_{\mathrm{CHN}, t}+\beta_{2} \ln \mathrm{GDP}_{\mathrm{i}, t}+\beta_{3} \ln \operatorname{dist}_{i}+\beta_{4} \ln _{\text {OFDI stock }}{ }_{i, t-n} \\
& +X \theta+\omega_{t}+\varepsilon_{i, t}
\end{aligned}
$$

In the equation, Chinese export to the country $i$ EXP is explained by the GDP of China, the GDP of country $i$, and the geographical distance, which are the proxies for commodity supply, demand capacity, and transportation costs, respectively. They are the basic variables in the gravity model. The key explanatory variable is the lagged term of OFDI stock that China has invested in country $i$. As mentioned earlier, this can avoid the omitted bias problem of regression estimation caused by the simultaneity between the OFDI flow and trade. At the same time, the lagged term of OFDI takes the time lag of investments forming actual production capacities in the host country into consideration. In this paper, I consider the model with lag phases of investment stock (i.e., $n=1,2,3$.). Subsequent regressions show the results with the current flow and current stock as the core explanatory variables, which directly assesses the impact of different core explanatory variables on empirical results. Other control variable $X$ and the factors that capture country heterogeneities are fully controlled, which includes a neighboring dummy, a common language dummy (i.e., the official language is Chinese or English $^{6}$ ), a free trade agreement (FTA) with China dummy, OECD member country dummy, and WTO member dummy. In addition, continent dummies (Asia, Europe, Africa, North America, Latin America, and Oceania) and law origin dummies (Anglo-American Legal System, French civil law, German law, and Nordic law) are also controlled in the regressions. $\Omega t$ is the year fixed effect, which can control the collision of global macroeconomic fluctuations on China's export to other countries.

In order to get a robust empirical conclusion, based on the mixed regression model (POLS), the disturbance term can be decomposed: $\varepsilon_{i, t}=\mu_{i}+v_{i, t}$, the empirical model can be rewritten as a fixed-effects model (FE):

$$
\begin{aligned}
\ln \mathrm{EXP}_{i, t}= & \beta_{1} \ln \mathrm{GDP}_{\mathrm{CHN}, t}+\beta_{2} \ln \mathrm{GDP}_{\mathrm{i}, t}+\beta_{3} \ln \text { dist }_{i}+\beta_{4} \operatorname{ln~OFDI~stock~}_{i, t-n} \\
& +Z \gamma+\omega_{t}+\mu_{i}+v_{i, t}
\end{aligned}
$$

In the model, all time-invariant dummies are classified as country fixed effects $\mu_{i}$, so they are no longer identifiable. But using the fixed-effects model allows me to obtain the "within-group" consistent estimators of other variables in the gravity model. They can be compared with the results of pooled OLS regressions to obtain a robust conclusion.

The dataset used in this paper is a panel of Chinese OFDI and export trade from 2003 to 2014. The data of OFDI is from "The Statistical Bulletin of Foreign Direct Investment of China", the data of export is from "The China Statistic Yearbook" of various years. The GDP of China and other countries are from the world development indicator database of the World Bank. Other data, such as geographic distance from China, language, law origins, and other country characteristics are from the CIA World Factbook and the France International Economics Research Center (CEPII) database. Before running the regressions, data was processed as follows: 
(1) Host countries with investment stock less than $\$ 100$ million and continuous observations less than 5 years are dropped from the sample, which can avoid the attenuation bias caused by measurement error problem.

(2)Investments to typical offshore financial centers, Hong Kong, and Macau are deleted. Basically, these investments set "shell" companies for capital transfer, tax avoidance, and even some of the illegal activities. Eventually, these investments flow to other countries or even home, which involves no actual economic activities such as employment, production, and operation in the host country (Wang 2013). They would have no effect on the export trade so keeping these observations would lead to false conclusions.

(3) Taking natural logarithm of the continuous variables. This can eliminate the problem of heteroskedasticity and extreme value of variables with large value, such as trade, GDP, and geographical distance. The regression coefficients obtained by logged data on both sides of the equation can be interpreted as the elasticity coefficients, which have clear economic meanings.

With the procedures described above, panel date of 155 countries from 2004 to 2014 is acquired, which contains 33 developed countries, and 122 developing countries. For the estimation method of model, Eqs. (1) and (2) are log-linearized from the original form of gravity model:

$$
\mathrm{EXP}_{i, t}=\alpha \mathrm{GDP}_{\mathrm{CHN}, t}^{\beta_{1}} \mathrm{GDP}_{i, t}^{\beta_{2}} \operatorname{dist}_{i}^{\beta_{3}} \text { OFDI stock }{ }_{i, t-n}^{\beta_{4}} X^{\theta} \eta_{i, t}
$$

Among the variables, $\eta_{i, t}$ is the independent error term which satisfies the condition: $E\left(\eta_{i, t} \mid \mathrm{GDP}_{\mathrm{CHN}, t}, \mathrm{GDP}_{i, t}\right.$, dist $_{i}$, OFDI stock $\left._{i, t-n}, X\right)=1$

We can obtain:

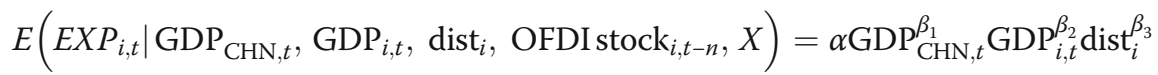

OFDI stock ${ }_{i, t-n}^{\beta_{4}} X^{\theta}$ However, after the log-linearization, we can get $E\left(\ln \eta_{i, t}\right) \neq 1 \mathrm{n} E\left(\eta_{i, t}\right)=$ 0 according to the Jensen inequality. Therefore, the error term $\varepsilon_{i, t}, v_{i, t}$ in Eqs. (1) and (2) cannot satisfy the classical assumption of zero mean. In fact, $E\left(1 \mathrm{n} \eta_{i, t}\right)$ depends not only on $E\left(\eta_{i, t}\right)$ but also correlates with higher order distributions of $\eta_{i, t}$. If the higher order moments of $\eta_{i, t}$ is correlated with the explanatory variables, OLS estimation would suffer from endogenous bias. ${ }^{7}$

Therefore, this paper uses the Poisson pseudo-maximum likelihood estimation proposed by Silva and Tenreyro (2006). ${ }^{8}$ Hao and Ma (2012) used the Monte Carlo simulations to compare the results of PPML and other commonly used estimation methods of the gravity model (OLS, NLS, Tobit). They found that the estimation error of PPML is the smallest and the estimation of factors such as FTA is more conservative and prudent compared with OLS.

\section{Results and discussion}

\section{The estimation results of full sample}

Table 1 shows the regression results of full sample. Models (1), (2), and (3) show the results of pooled OLS, with the one to three lag of OFDI as the explanatory variables respectively. Models (4), (5), and (6) add the individual fixed effects of the host 
Table 1 The effect of OFDI on export trade: the full sample (PPML estimation)

\begin{tabular}{|c|c|c|c|c|c|c|}
\hline $\begin{array}{l}\text { Explanatory variable: } \\
\text { China's exports to the host country }\end{array}$ & (1) & (2) & (3) & (4) & (5) & (6) \\
\hline 1-year lag of OFDI stock & $\begin{array}{l}0.073 \\
(1.52)\end{array}$ & - & - & $\begin{array}{l}-1.83 \times 10^{-5} \\
(-0.00)\end{array}$ & - & - \\
\hline 2-year lag of OFDI stock & - & $\begin{array}{l}0.064 \\
(1.29)\end{array}$ & - & - & $\begin{array}{l}-0.012 \\
(-0.72)\end{array}$ & - \\
\hline 3-year lag of OFDI stock & - & - & $\begin{array}{l}0.053 \\
(1.07)\end{array}$ & - & - & $\begin{array}{l}-0.019 \\
(-1.07)\end{array}$ \\
\hline Control variables in the gravity model & Yes & Yes & Yes & Yes & Yes & Yes \\
\hline Individual fixed effect & No & No & No & Yes & Yes & Yes \\
\hline N & 1584 & 1434 & 1282 & 1584 & 1434 & 1282 \\
\hline$R^{2}$ & 0.606 & 0.598 & 0.593 & 0.969 & 0.971 & 0.972 \\
\hline
\end{tabular}

Note: (1) the control variables in the gravity model include GDP of the host country, GDP of China, geographic distance, the border dummy, the common language dummy, the FTA with China dummy, the OECD dummy, the WTO dummy, regional fixed effects, legal origin fixed effects, year fixed effects; (2) the value in the brackets is the $t$ statistic; (3) the estimation of the standard errors of coefficients is clustered on the individual country level

country, ${ }^{9}$ all models control for the common explanatory variables in the gravity model of international trade.

The core explanatory variables in Table 2 are replaced with the current flowing and stock of OFDI, which are commonly used in existing literature. Models 1 and 2 provide the regression results of single variable setting. OFDI shows the significant accelerating role on export with the elasticity value higher than 0.4 , which is close with the results in the literature that use co-integration analysis (Xiang 2009; Zhang 2012; Liu and Xie 2014); models 3 and 4 are modified on the basis of former estimation method and show the PPML regression results. The coefficients of OFDI variables decreased to some extent, but are still statistically significant. Models 5 and 6 further modify the model specification and add the control variables in gravity model as Table 1, which further weakens the coefficient value and statistical significance. The only difference of models 5 and 6 with Table 1 is the selection of key variables. Compared with these two tables, the coefficient estimation and $t$-statistics in OFDI current flowing, current stock, and lag stock are successively declining, which confirms the conjecture of second part in this paper. It is due to the simultaneity of political relationship between China and the host country; the current OFDI flow and the trade flow tend to show high positive

Table 2 The effect of OFDI on export trade: the full sample (wrong specifications)

\begin{tabular}{|c|c|c|c|c|c|c|}
\hline \multirow{2}{*}{$\begin{array}{l}\text { Explanatory variable: } \\
\text { China's exports to the host country }\end{array}$} & \multicolumn{2}{|c|}{ Estimation method: OLS } & \multicolumn{4}{|c|}{ Estimation method: PPML } \\
\hline & (1) & (2) & (3) & (4) & (5) & (6) \\
\hline Current OFDI flow & $\begin{array}{l}0.459^{* * *} \\
(11.33)\end{array}$ & - & $\begin{array}{l}0.390^{* * *} \\
(11.51)\end{array}$ & - & $\begin{array}{l}0.206^{* * *} \\
(3.73)\end{array}$ & - \\
\hline Current OFDI stock & - & $\begin{array}{l}0.487^{* * *} \\
(10.44)\end{array}$ & - & $\begin{array}{l}0.432^{* * *} \\
(10.21)\end{array}$ & - & $\begin{array}{l}0.075 \\
(1.60)\end{array}$ \\
\hline Control variables in the gravity model & No & No & No & No & Yes & Yes \\
\hline N & 1354 & 1762 & 1354 & 1762 & 1331 & 1730 \\
\hline$R^{2}$ & 0.291 & 0.286 & 0.299 & 0.298 & 0.664 & 0.617 \\
\hline
\end{tabular}

Note: (1) the control variables in the gravity model include GDP of the host country, GDP of China, geographic distance, the border dummy, the common language dummy, the FTA with China dummy, the OECD dummy, the WTO dummy, regional fixed effects, legal origin fixed effects, year fixed effects; (2) the value in the brackets is the $t$ statistic; (3)*** is the significant level of $1 \%$; (4) the estimation of the standard errors of coefficients is clustered on the individual country level 
correlations. So using the current investment flow or stock as the key explanatory variable of export tends to overestimate the promoting role of OFDI on export (Zhang 2007; Zhang 2012; Zhou and Niu 2012; Zhang and Huang 2013; Wang et al. 2014). In summary, Tables 1 and 2 jointly show that the inappropriate variable selection, model misspecification, and wrong estimation methods are the reasons why the "promotion effect" is overestimated. Only simultaneously correcting for the three factors can the real impact of China's OFDI on export trade be shown. In general, the impact of OFDI on export is weak.

\section{Estimation results of sub-sample}

Taking into account the obvious differences in investment motivations and industrial attributes that China invests in developed countries and developing countries, the investments that flow to developed countries are mainly the wholesale and retail industry and manufacturing industry while that investment flowing to developing countries are mainly the mining industry (Wang 2013). Heterogeneity exists in the effects of different types of FDI on export trade, so I consider running some sub-sample regressions. ${ }^{10}$

Table 3 provides the regression results of the developed country sub-sample. The specification of each model is consistent with Table 1 . The regression results show that the effect of FDI from China to developed countries on export is negative, but not significant, which has slight substitution effect. It is consistent with the reality: a large fraction of Chinese OFDI to developed countries is to cross the trade barriers. The motivation is to seek market opportunities, which has export substitution effect. Some Chinese OFDI to developed countries is to obtain patents, technology, and other strategic assets, which has no trade effect theoretically. As a result, China's OFDI in developed countries shows a slight export substitution effect.

Table 4 provides the regression results of the developing country sub-sample. Model 1 shows that the elasticity between foreign direct investment and export is 0.12 with significance level of $5 \%$. From a practical point of view, Chinese OFDI in developing countries is mostly in the mining industry. The construction of mines, oil wells, and

Table 3 The effect of China OFDI on export trade: regression of sub developed sample (the estimation of PPML)

\begin{tabular}{lllllll}
\hline $\begin{array}{l}\text { Explanatory variable: } \\
\text { China's exports to the host country }\end{array}$ & $(1)$ & (2) & (3) & (4) & (5) & (6) \\
\hline 1-year lag of OFDI stock & -0.038 & - & - & -0.019 & - & - \\
& $(-0.64)$ & & & $(-0.42)$ & \\
2-year lag of OFDI stock & - & -0.056 & - & - & -0.020 & - \\
& & $(-0.83)$ & & & $(-0.44)$ & \\
3-year lag of OFDI stock & - & - & -0.078 & - & - & -0.013 \\
& & & $(-1.00)$ & & & $(-0.32)$ \\
Control variables in the gravity model & Yes & Yes & Yes & Yes & Yes & Yes \\
Individual fixed effect & No & No & No & Yes & Yes & Yes \\
$N$ & 339 & 306 & 274 & 339 & 306 & 274 \\
$R^{2}$ & 0.549 & 0.549 & 0.550 & 0.980 & 0.983 & 0.987
\end{tabular}

Note: (1) the control variables in the gravity model include: GDP of the host country, GDP of China, geographic distance, the border dummy, the common language dummy, the FTA with China dummy, the OECD dummy, the WTO dummy, regional fixed effects, legal origin fixed effects, year fixed effects; (2) the value in the brackets is the t statistic; (3) the estimation of the standard errors of coefficients is clustered on the individual country level 
Table 4 The effect of China OFDI on export trade: regression of sub developing sample (the estimation of PPML)

\begin{tabular}{lllllll}
\hline $\begin{array}{l}\text { Explanatory variable: } \\
\text { China's exports to the host country }\end{array}$ & $(1)$ & $(2)$ & $(3)$ & (4) & (5) & (6) \\
\hline 1-year lag of OFDI stock & $\begin{array}{l}0.120^{* *} \\
(1.96)\end{array}$ & - & - & 0.028 & - & - \\
2-year lag of OFDI stock & - & $0.105^{*}$ & - & - & 0.003 & - \\
& & $(1.69)$ & & & $(0.19)$ & \\
3-year lag of OFDI stock & - & - & 0.090 & - & - & -0.013 \\
Control variables in the gravity model & Yes & Yes & Yes & Yes & Yes & Yes \\
Individual fixed effect & No & No & No & Yes & Yes & Yes \\
$N$ & 1245 & 1128 & 1008 & 1245 & 1128 & 1008 \\
$R^{2}$ & 0.575 & 0.565 & 0.557 & 0.962 & 0.964 & 0.964 \\
\hline
\end{tabular}

Note: (1) the control variables in the gravity model include GDP of the host country, GDP of China, geographic distance, the border dummy, the common language dummy, the FTA with China dummy, the OECD dummy, the WTO dummy, regional fixed effects, legal origin fixed effects, year fixed effects; (2) the value in the brackets is the $t$ statistic; (3) **,* is the significant level of $5 \%, 10 \%$ respectively; (4) the estimation of the standard errors of coefficients is clustered on the individual country level

processing facilities needs a lot of building materials, machineries, and equipments. But the host countries with abundant natural resources in Africa and Latin America have weak industrial development and chaotic business environment. A big problem with these host countries is that they often fail to provide Chinese firms operating there with up-to-standard raw materials, intermediate goods, machineries, and equipments. Market failures such as weak contract awareness and sluggish communication caused by long distance of culture and language are also prevalent. Therefore, Chinese firms that have invested in these host countries often need the intra-firm channels to purchase the inputs and equipments they need, which promote the export trade from China to the host countries (Chih-Fan and Dong 2013). In addition, the brand construction of China leaves the overseas market with the impression of "fair price for high quality". These subtle impacts contribute to the promoting effect of OFDI on export. ${ }^{11}$

Nevertheless, we should still be cautious to model 1. In the setting, the coefficient of 1 -year lag of OFDI stock is 0.12 , which indicates that $1 \%$ increasing of the OFDI to developing country only leads to $0.12 \%$ increase in export trade. The influence is small. Moreover, in models 4 to 6 , the elasticity coefficient is closer to zero with the no statistical significance after controlling for the individual fixed effects. The coefficient of OFDI in model 6 even turns to be negative. All in all, a cautious conclusion drawn from Table 4 is that the promoting effect of OFDI on export is weak.

\section{Dynamic trend and discussions of contribution}

This section analyzes the dynamic trend of OFDI's impact on export. Based on estimations of model 1 of the full sample and the two sub-samples, Fig. 1 reports the estimated coefficient of elasticity between OFDI and export of the full sample, developed country sample, and developing country sample.

Figure 1 reveals some interesting information: from the point of view of the full sample, in earlier years (before the year of 2008), although the elasticity of ODFI on export is positive, the estimated value is small and not significant. After 2010, the elasticity coefficient of promoting reached more than 0.1 with some statistical significance. 


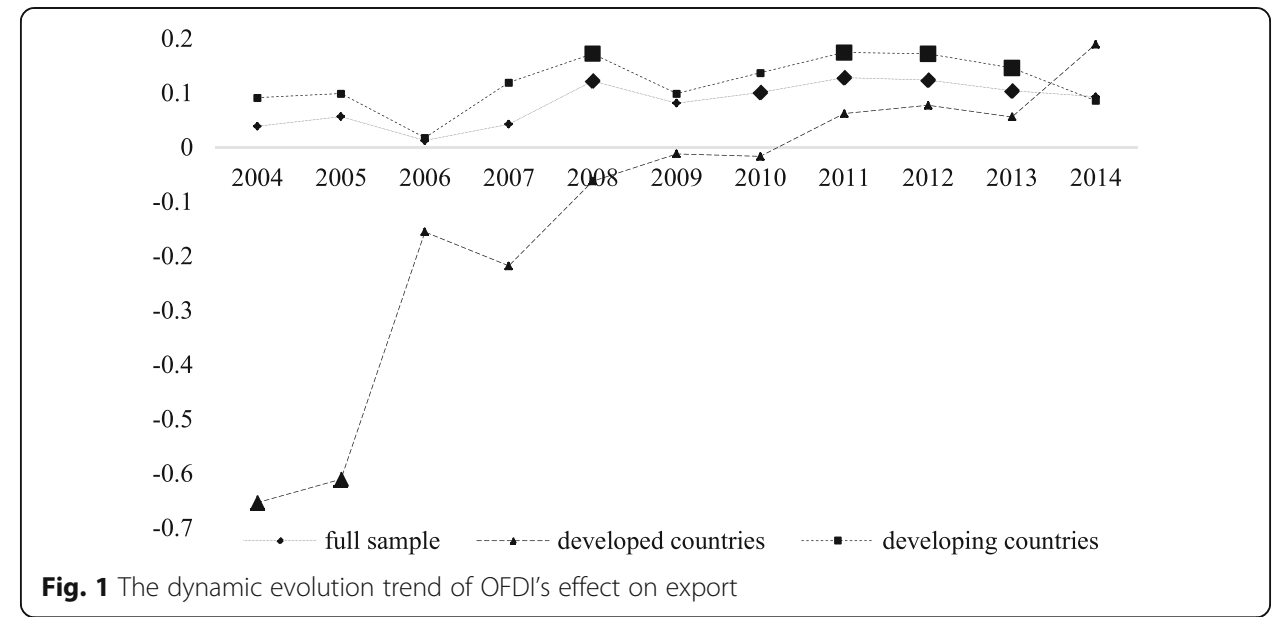

One possible reason is that the effect of OFDI on export may depend on the size of OFDI. In the early period of China carrying OFDI, flow and stock of OFDI less than billions of dollars is difficult to cast influence on export trade. As time goes by, the increase in the stock of investment has an increasing impact on export. Of course, another possible changing reason may be the structure evolution of industries, destinations, and motivations that China invests. In early years, China preferred to invest in developed countries, with the purpose of obtaining patents, frontier technology, and other strategic assets. However, Chinese enterprises often face obstructions in administrative procedures when acquiring the enterprises that have advanced technology. Some contracts are revoked for the reason of "national security". What is worse, some completed acquisition cases do not have expected economic outcomes. In recent years, Chinese OFDI invested more in countries with abundant natural resources. As mentioned before, it is due to external market failures or the host countries' inadequate supporting industries that result in the increased export of intermediate products, machinery, and equipment of China. The changing industrial structure of OFDI as well as the characteristics of the host country may be the important reasons for the evolution of the export effect.

The lines of the sub-samples in the figure show that OFDI in developed countries has a tendency of switching from substitution to complementation. But the coefficients of elasticity of recent years are not significant. However, the OFDI in the developing countries shows the export promotion effect. In recent years, the coefficients and the significant level have shown a trend of improvement.

At last, this paper analyzes the contribution of OFDI to export trade. The question we are interested in is that if OFDI had an effect on export trade, then to what the extent that China's increasing export trade could be explained by the OFDI. Specifically, the calculating formula of the contribution is as follows:

$$
\text { Contribution }=\frac{\beta \times\left[\left(\text { OFDI }_{\text {stock }_{t}} / \text { OFDI }_{\text {stock }_{t-T}}\right)^{\frac{1}{T}}-1\right]}{\left(\text { export }_{t-1} / \text { export }_{t-1-T}\right)^{\frac{1}{T}}-1}
$$

$\beta$ is the estimated elasticity coefficients of OFDI on export trade in the regressions, $\left(\mathrm{OFDI}_{\text {stock }_{t}} / \mathrm{OFDI}_{\text {stock }_{t-T}}\right)^{\frac{1}{T}}-1$ and $\left(\text { export }_{t-1} / \text { export }_{t-1-T}\right)^{\frac{1}{T}}-1$ is the average growth rate of OFDI stock and export trade in the sample period $T$, respectively. 
For the full sample, the OFDI stock from 2003 to 2013 increased from $\$ 33.2$ billion to $\$ 660.48$ billion with the average annual growth rate of $34.86 \%$. The export trade from 2004 to 2014 increased from $\$ 593.33$ billion to $\$ 2.34$ trillion with the average growth rate of $14.72 \%$. According to the results of model 1 in Table 1 , the point estimation of elastic coefficient is 0.073 . The calculated contribution degree is estimated to be $17.29 \%$. However, the estimated coefficient is not significant. Therefore, there is no statistical difference between this contribution value and zero.

I compare this result with the conclusions obtained from existing literature. For example, the empirical study of Xiang (2009) showed that the elasticity coefficient of OFDI is 0.9. According to the formula (3), the contribution of OFDI on export reached $231.27 \%$, which means that only the factor of OFDI has a larger influence on export than the actual growth rate in the sample period. Therefore, the impact of other factors on export must be collectively negative to "counter-balance" this effect, which is an impossible situation. And many other estimation values in the existing literature also calculate the contribution of OFDI on export to be more than $100 \%$. According to the analysis of this paper, this kind of error may be explained by the inappropriate variable selection, model misspecification, and wrong estimation method. For the two sub-samples of developed countries and developing countries, the absolute value of OFDI's contribution degree to export in the sample period is no more than $20 \%$. In short, the impact of Chinese OFDI on export trade is relatively limited.

\section{Conclusions}

In recent years, China's OFDI has developed rapidly. The influence of OFDI on export has attracted increasing attention in academic studies. With the "One belt and One road" policy recently proposed by China, OFDI and international trade would play more important roles in the economic development of China and related economies. Clarifying the relationship between OFDI and export will be conductive to provide a scientific reference for policy development and analysis of welfare gains and losses, which is of great significance. At present, most of the researches in China have got the conclusion that OFDI significantly promotes export trade. Upon reviewing these studies, this paper corrects inappropriate variable selection, model misspecification, and wrong estimation methods and re-examines the effect of OFDI on export trade. The empirical results overthrow the conclusions of existing literature: In a word, the effect of OFDI on export is relative small. OFDI in developed countries has a slight substitution for export while ODFI in developing countries has a certain degree of promotion effect on export.

The policy implication in this paper is that in the situation of the ongoing decline of the global economy and shrinking external demand, OFDI is not an effective way to promote export growth. This is contrary to what some researchers have suggested. Indeed, Chinese ODFI has many benefits: First is that according to Kojima's theory of "marginal industry transfer" and the theoretical predictions of the New Structural Economics, OFDI is conductive to transfer the labor-intensive industries that have relative simple technology and disappearing comparative advantages to the host countries of lower level of development. This benefit can not only contribute to the higher rate of return in Chinese capital and technology, which is conductive to the domestic economic restructuring and upgrading, but can also help poor countries out of the 
"poverty trap". For example, the investment of Hua Jian shores corporation in Ethiopia is a typical successful case, which creates the "Hua Jian" mode that can be replicated in the future of Chinese OFDI. Second is that the investment of these state-owned enterprises such as "CRRC," "CRE," "CSCEC," and "Chinese Communications Construction Company" not only contributes to the reduction of overcapacity in domestic industries such as cement and steel but also conducts to the construction and consolidation of political relations between China and host countries, which facilitates to the strategic layout of national interests. These are real benefits of foreign direct investment. However, the atrophy in export demand is mainly associated with economic situation of trading partners with poor economic situation. This gap is difficult to be made up by the promoting effect of OFDI. On the other hand, the change of China's economic development stage also determines that the advantages of export trade acquired by the cheap factor inputs and scale economies are no longer the main driving force of economic growth. This extensive growth mode brings the threat of domestic environment pollution and resource exhaustion, large quantity of low-priced export commodities often lead to trade frictions and disputes, which is unsustainable in the new normal economy. Therefore, with the upgrading of the factor endowment structure and the changing comparative advantage of trade, China's upgrading of export structure should be gradually realized. At the same time, the export structure in China should also be gradually upgraded to the export model with the high technology and high value-added products. It is necessary to reduce the dependence of economic and employment on export trade and complete the transformation from "export oriented" to "domestic demand driven" economy.

\section{Endnotes}

${ }^{1}$ Jiang and Jiang (2014), Mao and Xu (2014), and Qiao and $\mathrm{Hu}$ (2015) provide empirical evidence on the micro level. These papers integrate the China industrial enterprises statistics data, customs trade database, and overseas investment enterprises list and use methods of matching and difference-in-difference. They found that the OFDI of enterprises basically promoted the export. However, different investments with different motivation have different effects. Although this micro approach of studying the effect of OFDI on export is more direct, the publicly database of industrial enterprises has the data available before 2007, which dates back nearly a decade ago. The pattern of OFDI and international trade of China change a lot during this period. The effectiveness of conclusion out of the sample remains to be considered. Indeed, the problem that export and investment does not directly match is inevitable in the macro level. The conclusion is also needed to be further studied. I thank the reviewers for reminding me of this issue.

${ }^{2}$ I thank the reviewer for the advice of lagging more years in OFDI.

${ }^{3}$ The fourth part of this paper will discuss the economic significance of the elasticity coefficient.

${ }^{4}$ The Hausman test is generally used to compare the regression estimates of the fixed-effect model and the random-effect mode to test for systematic differences. If the differences are not statistically significant, the random effects model could be more efficient. However, the results of Hausman tests are posterior and would change with the different samples and model specifications. It is uncertain whether the random-effect model could be used in the estimation of gravity model. 
${ }^{5}$ Since the dataset used in this paper has a large overlap with the sample of Liu et al. (2014), this conjecture can be verified. Using the same model specification and the system GMM estimation method, we find that if the variable of Chinese GDP were controlled in the model of trade gravity, the stock of OFDI would not be significant. If the variable of Chinese's GDP is deliberately omitted, the stock of OFDI is significantly positive and the estimation coefficients is similar with their results. Limited by space, the result is not shown in the empirical part. The empirical data and STATA codes are available from author upon request.

${ }^{6}$ Although English is not the official language of China, there are lots of Chinese studying English, so it has a great influence on China.

${ }^{7}$ At this point, the variance of the $\eta_{i, t}: \operatorname{Var}\left(\eta_{i, t}\right)=f\left(\mathrm{GDP}_{\mathrm{CHN}, t}, \mathrm{GDP}_{i, t}\right.$, dist $_{i}$, OFDI stock ${ }_{i, t}$ $\left.-{ }_{-n}, X\right) \neq$ constant

${ }^{8}$ Confined in this paper, the details of PPML methods are not shown, readers can see the paper of Silva and Tenreyro (2006), (The Review of Economics and Statistics). Chinese literature such as Sun Lin and Ni Kaka (2013), Tian Wei et al. (2013) used this method.

${ }^{9}$ The interpretation of fixed effect model is different from that of the pooled OLS model. The estimated coefficient reflects the within-group effect, which means that $1 \%$ increase of Chinese OFDI stock to one specific host country contributes to several percentage increase of export.

${ }^{10}$ In Table 1, the coefficients of Chinese and host country's GDP are significantly positive. The coefficient of geographic distance is significantly negative, which is in line with expectation. The signs of other control variables are similar with the existing literature. Limited by the space, this paper does not show the coefficients and $t$-statistic.

${ }^{11}$ Constrained by space limitations, the estimation of sub-sample does not provide the regression results that are based on the wrong variable selection, model specification, and estimation method.

\footnotetext{
Acknowledgements

This paper is supported by the National Social Science Fund of China (Grant: 15CJLO25) and the NSE Special Research Fund granted by the Center for New Structural Economics of Peking University.
}

Competing interests

The author declares that he has no competing interests.

Received: 12 August 2016 Accepted: 12 October 2016

Published online: 27 October 2016

References

Cai R, Liu Q (2004) Are the Chinese international direct investment and trade complementary? The empirical analysis based on the marginal industry theory. World Econ Study 8:64-70.

Chen L, Yang Z, Hou Z (2010) Export driven or export substitution? - the marginal industry strategy test of Chinese OFDI. Finance Trade Econ 2:78-85.

Hu B, Qiao J (2013) The trade effect of China's OFDl_based on dynamic panel model system GMM method. Econ Manag 4:11-19.

Hao J, Ma H (2012) The new development of gravity model and the test of Chinese foreign trade. J Quant Tech Econ 10:52-68.

Jiang G, Jiang D (2014) Export effect of Chinese OFDI, Econ Res J 5:160-173.

Chih-Fan L, Dong Q (2013) The export effect of Chinese OFDI: inhibition or promotion based on the empirical study of panel data of 21 countries. Comments Prod Ind 5:152-160.

Liu H, Nie F (2014) Hollow effect of Chinese OFDI of manufacturing industry. China Ind Econ 4:83-96.

Liu X, Gou Q, Lu F (2014) The impact analysis of Chinese OFDI on export. Working Paper Econ Res, WP672

Liu Z, Xie R (2014) The empirical analysis of country effect of Chinese OFDI on ASEAN. World Econ Stud 6:80-86.

Mao Q, Xu J (2014) Does Chinese OFDI promote or inhibit the enterprise export. J Quant Tech Econ 9:3-21.

Qiao J, Hu B (2015) How FDI affect export-based on the matching of manufacturing enterprises. J Int Trade 4:126-136.

Wang B (2013) The misunderstood official data-the real OFDI of China. Int Econ Rev 1:61-74. 
Wang S, Tian T, Xie R (2014) The trade effect research of Chinese FDI. World Econ Stud 10:80-86.

Wang S, Xiang J (2014) Creation or substitution —-the mechanism research of Chinese FDI on trade. World Econ Res 6:66-72.

Xiang B (2009) The trade effect research of Chinese FDI—based on the co-integration analysis of panel data, Finance Trade Econ 4:77-82.

Zhang C (2012) The trade effect research of OFDI, J Quant Tech Econ 6:74-85.

Zhang J, Huang P (2013) Replacement of exports or promoting exports-the research on the effect of FDI on export. $J$ Int Trade 3:95-103.

Zhang R (2005) The analysis of the relationship between OFDI and international trade. World Econ Stud 3:23-27.

Zhang Y (2007) The relationship between OFDI and trade: complementary or alternative. J Int Trade 6:87-93.

Zhou X, Niu R (2012) Chinese OFDI and the trade effect-based on the empirical research on panel gravity model. Int Econ Trade Res 5:69-81.

Anderson JE, van Wincoop E (2004) Trade costs. J Econ Lit 42(3):691-751

Anderson JE (1979) A theoretical foundation for the gravity equation. Am Econ Rev 69(1):106-116

Belderbos R, Sleuwaegen L (1998) Tariff jumping DFl and export substitution: Japanese electronics firms in Europe. Int Ind Organ 16(5):601-638

Bergstrand JH (1985) The gravity equation in international trade: some microeconomic foundations and empirical evidence. Rev Econ Stat 67(3):474-481

Buckley PJ, Casson M (1981) The optimal timing of a foreign direct investment. Econ J 91(361):75-87

Chen W, Tang H (2014) The dragon is flying west: micro-level evidence of Chinese outward direct investment. Asian Dev Rev 31(2):109-140

Head K, Ries J (2001) Overseas investment and firm exports. Rev Int Econ 9(1):108-122

Helpman E, Melitz MJ, Yeaple SR (2004) Export versus FDI with heterogeneous firms. Am Econ Rev 94(1):300-316 Helpman E (1984) A simple theory of international trade with multinational corporations. J Pol Econ 92(3):451-471 Hirsch S (1976) An international trade and investment theory of the firm. Oxford Econ Pap 28(2):258-270 Horst T (1972) Firm and industry determinants of the decision to invest abroad: an empirical study. Rev Econ Stat 54(3):258-266 Kojima K (1975) International trade and foreign investment: substitutes or complements. Hitotsubashi J Econ 16(1):1-12 Lipsey RE, Weiss MY (1981) Foreign production and exports in manufacturing industries. Rev Econ Stat 63(4):488-494

Lipsey RE, Weiss MY (1984) Foreign production and exports of individual firms. Rev Econ Stat 66(2):304-308

Mundell RA (1957) International trade and factor mobility. Am Econ Rev 47(3):321-335

Oberhofer H, Pfaffermayr M (2012) FDI versus exports: multiple host countries and empirical evidence. World Econ 35(3):316-330

Schmitz A, Helmberger P (1970) Factor mobility and international trade: the case of complementarity. Am Econ Rev 60(4):761-767

Silva S, Tenreyro S (2006) The log of gravity. Rev Econ Stat 88(4):641-658

Tinbergen J (1962) An analysis of world trade flows in shaping the world economy. Twentieth Century Fund, New York Vernon R (1966) International investment and international trade in the product cycle. Q J Econ 80(2):190-207

\section{Submit your manuscript to a SpringerOpen ${ }^{\circ}$ journal and benefit from:}

- Convenient online submission

Rigorous peer review

- Immediate publication on acceptance

- Open access: articles freely available online

- High visibility within the field

- Retaining the copyright to your article 